\title{
Directly observed therapy in a patient with refractory hypocalcemia
}

Ellen Njagi, Julie Kyaw-Tun,

Department of Diabetes and Endocrinology, Calderdale Royal Hospital, Calderdale and Huddersfield NHS Foundation Trust, Huddersfield HD3 3EA

\section{Introduction}

Hypocalcaemia in acquired
hypoparathyroidism responds to
oral vitamin $D$ and calcium
replacement. We describe a case
of persistent symptomatic
hypocalcaemia despite
conventional therapy plus
Teriparatide (which is a
recombinant form of parathyroid
hormone) and managed with
supervised
administration.

\section{Case Summary}

We report a 45-year-old man who developed acquired primary hypoparathyroidism based on a low serum adjusted calcium level and low parathyroid hormone level.

His past medical history included recurrent chronic anaemia requiring multiple transfusions since 2011. He was an ex- intravenous drug user, and suffered from chronic bilateral venous leg ulcers, and liver cirrhosis following Hepatitis $\mathbf{C}$ infection.

With regards to the recurrent chronic anaemia, he has been extensively investigated by haematology and gastroenterology colleagues, with no cause found. However, his Ferritin levels averaged around $30 \mathrm{much} / \mathrm{L}$, suggesting blood loss and iron deficiency as the cause. We looked into the possible theory of exposure to citrate from multiple bloods transfusions as a cause of hypocalcaemia. But an avoidance of blood transfusions for two weeks did not prevent hypocalcaemia.

\section{Management}

Despite using doses of up to $8 \mathrm{mcg}$ Calcitriol daily, his calcium levels fell recurrently and he required repeated intravenous calcium infusions. Vitamin D levels were repleted, as were Magnesium levels corrected as best possible $(>0.50$ $\mathrm{mol} / \mathrm{L}$ ) using supplements and Amiloride (24 hour urine magnesium was $0.93 \mathrm{mmol} / \mathrm{L})$. He was not on a proton pump inhibitor.

Finally, Teriparatide $40 \mathrm{mcg}$ was added to a combination of Calcitriol $2.5 \mathrm{mcg}$, calcium carbonate $10 \mathrm{mg}$, Adcal D3, colecaciferol 800 units, magnesium aspartate $13 \mathrm{~g}$, and Amiloride $20 \mathrm{mg}$ daily. Yet, recurrent hypocalcaemia continued to occur requiring Infusions almost twice weekly.

Compliance with medications was questioned repeatedly with both the patient and nurses during his prolonged admission. Directly observed therapy for all his medication was carried out. With this, we were able to maintain calcium levels above the acceptable range and the patient did not require intravenous calcium replacement for 3 months.

\section{Investigations}

\begin{tabular}{|c|c|}
\hline Calcium & $152 \mathrm{mmol} / \mathrm{l}$ \\
\hline Vitamin D & $10.8 \mu \mathrm{g}$ \\
\hline PTH & $1.40 \mathrm{ng} / \mathrm{L}$ \\
\hline Magnesium & $0.51 \mathrm{mmol} / \mathrm{L}$ \\
\hline $\begin{array}{l}\text { Urine } \\
\text { creatinine }\end{array}$ & $\begin{array}{l}2.0 \mathrm{mmol}(3.72 \mathrm{~mm} \\
\mathrm{ol} / 24 \mathrm{hr})\end{array}$ \\
\hline Urine Calcium & $<0.25 \mathrm{mmol}$ \\
\hline $\begin{array}{l}\text { Urine } \\
\text { Magnesium }\end{array}$ & $\begin{array}{l}0.93(1.73 \mathrm{mmol} / 2 \\
4 \mathrm{hrs}\end{array}$ \\
\hline $\begin{array}{l}\text { Urine } \\
\text { Phosphate }\end{array}$ & $\begin{array}{l}3.51(6.5 \mathrm{mmol} / 24 \\
\mathrm{hrs}\end{array}$ \\
\hline$H B$ & 52 \\
\hline MCV & 60 \\
\hline Ferritin & \\
\hline
\end{tabular}

\section{Discussion and conclusion}

Non-compliance with
medication poses a
challenge in managing
chronic conditions.
Supervised treatment and
enhancing good doctor-
patient relationship will
increase likelihood of
adherence hence abating
admission due to acute
complications

\section{References:}

1. Giancarelli A, Birrer K, Alban R., Hypocalcemia - an adverse effect of massive blood tranfusion. $J$

Surgical Research 2016; 202: 18287 